\title{
Production of High Purity Boron Carbide
}

D.K. Bose, K.U. Nair and C.K. Gupta

Metallurgy Division, Bhabha Atomic Research Centre

Trombay, Bombay 400 085, India

\section{CONTENTS}

$\begin{array}{ll}\text { ABSTRACT } & 134 \\ \text { INTRODUCTION } & 134 \\ \text { PRINCIPLE AND PROCEDURE } & 134 \\ \text { RESULTS AND DISCUSSIONS } & 136 \\ \text { (i) Types of carbon as reducing agent } & 136 \\ \text { (ii) Boric acid to carbon ratio } & 137 \\ \text { (iii) Rate of heating and duration of test run } & 137 \\ \text { PROCESSING OF BORON CARBIDE FOR CONTROL } & \\ \quad \text { ROD AND SHIELDING APPLICATION } & 139 \\ \text { CONCLUSION } & 140 \\ \text { REFERENCES } & 140\end{array}$




\section{ABSTRACT}

The paper presents the results of investigations carried out on the preparation of boron carbide $\left(\mathrm{B}_{4} \mathrm{C}\right)$ by carbothermic reduction of boric acid serving as a source of boron in a graphite resistance furnace. Studies have been made with different charge composition, different forms of carbon and various rates of heating and times allowed for reduction. The paper also includes the processing treatments involving grinding and leaching given to the reduced carbide power to suit specific nuclear applications.

\section{INTRODUCTION}

Boron carbide is a well reputed abrasive material. It has also found application in many other areas. In nuclear industry it is well-known as an ideal control and shielding material due to its favourable neutron absorption characteristics in both thermal and epithermal energy ranges. Extreme hardness and low density of boron carbide have been found to be of great use in the development of light weight armour ceramic composites. Sintered boron carbide shapes are finding wide application in sand blasting nozzles, hard ceramic bearings and wire drawing dies. In the aerospace industry, boron carbide, due to its capacity to generate an intense amount of heat $(12400 \mathrm{kcal} / \mathrm{kg})$ when combined with oxygen, is finding use as a rocket propellant. Good adherent characteristics and resistance to high temperature and chemical attack also make boron carbide an excellent coating material for graphite throats of rocket nozzles.

Boron carbide is commercially produced by the carbothermic reduction of boric anhydride $\left(\mathrm{B}_{2} \mathrm{O}_{3}\right)$ at temperatures higher than $2000^{\circ} \mathrm{C}$ in either electric arc or resistance furnaces. The arc furnace product usually contains $70-75 \%$ boron associated with a high level of free carbon. The resistance furnace, on the other hand, yields carbide with boron content very close to the stoichiometric content (78.9\%). Apart from the carbothermic system, boron carbide can also be prepared by the magnesiothermic reduction of boron anhydride in the presence of carbon $/ 1,2 /$. This particular reduction technique yields very fine amorphous powder which is well suited for use in the fabrication of sintered products. The literature on the preparative metallurgy of boron carbide has also reported /3, 4/ chemical vapour deposition of carbide by hydrogen reduction of boron trichloride or bromide.
Published information on the carbothermic preparation of boron carbide is very limited. The present paper is devoted to providing a detailed account of the process as investigated for the production of boron carbide.

\section{PRINCIPLE AND PROCEDURE}

Reduction of boron anhydride with carbon proceeds in two stages according to the following reactions:

$$
\begin{aligned}
& \mathrm{B}_{2} \mathrm{O}_{3}+3 \mathrm{CO}=2 \mathrm{~B}+3 \mathrm{CO}_{2} \\
& 4 \mathrm{~B}+\mathrm{C}=\mathrm{B}_{4} \mathrm{C}
\end{aligned}
$$

The first stage of reduction of $\mathrm{B}_{2} \mathrm{O}_{3}$ with carbon monoxide becomes thermodynamically feasible only above $1400^{\circ} \mathrm{C}$. However, as reported by Morkovski et al. $15 /$ the reduction temperature is required to be maintained beyond $2000^{\circ} \mathrm{C}$ to achieve an enhanced rate of reduction accompanied by formation of $\mathrm{B}_{4} \mathrm{C}$ at the second stage.

The quality of boron carbide varies widely depending upon the techniques used for reduction. In an arc furnace the reduction is carried out at $2500^{\circ} \mathrm{C} / 5 /$ where boron carbide crystallises out from the melt. During solidification boron carbide decomposes pertectically to yield volatile boron and the resulting product becomes enriched with free carbon to the extent of $10-12 w t \%$. In a core or coreless furnace mode of production, reduction takes place without melting or with partial melting. In this case, by regulating the power input, free carbon content in the product can be controlled well below $1.0 \mathrm{wt} \%$.

Raw materials consisting of boric acid (SQ grade) and high purity petroleum coke powder from indigenous suppliers were used in this investigation. Table 1 presents the analyses of these raw materials as used in the present investigation.

A schematic diagram of a specially designed graphite resistance furnace used in the present investigation is shown in Fig. 1. The furnace shell (mild steel) was lined inside with $30 \mathrm{~mm}$ graphite plates with a backing of $50 \mathrm{~mm}$ thick ceramic insulating bricks. The shell was fitted with two water cooled and well insulated graphite terminal blocks. A graphite rod $(30 \mathrm{~mm}$ dia $96 \mathrm{~mm}$ long) fitted tightly between the terminal blocks served as heating element in the core. The power supply to the terminals was drawn from a high current $(2000$ amp, $40 \mathrm{v}$ ) single phase transformer.

In a typical reduction batch $50 \mathrm{Kg}$ of boric acid was mixed thoroughly with the requisite quantity 


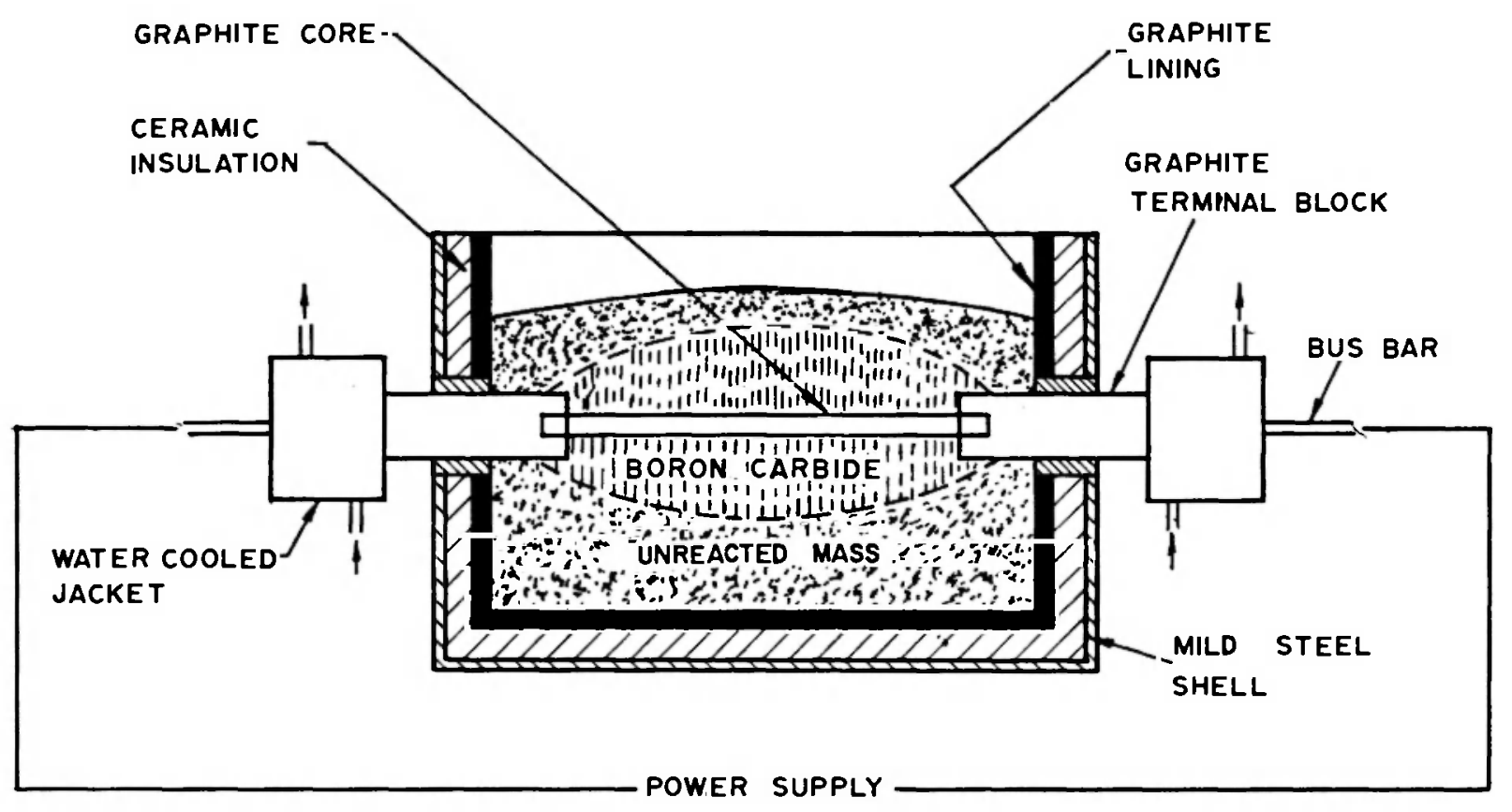

Fig. 1. Graphite resistance furnace used for the production of boron carbide.

TABLE 1: Chemical and sieve analyses of raw materials

\begin{tabular}{lc}
\hline Boric Acid & \\
\hline Boric Acid $\left(\mathrm{H}_{3} \mathrm{BO}_{3}\right)$ & $99.9 \%$ Max. \\
Impurities & \\
Sodium ( $\mathrm{Na})$ & $10.0 \mathrm{ppm}$ \\
Chloride (C) & $0.4 \mathrm{ppm}$ \\
Sulphate $\left(\mathrm{SO}_{3}\right)$ & $1.6 \mathrm{ppm}$ \\
Phosphate $\left(\mathrm{PO}_{4}\right)$ & $10.0 \mathrm{ppm}$ \\
Iron (Fe) & $2.0 \mathrm{ppm}$ \\
Heavy metal (as $\mathrm{Pb})$ & $2.0 \mathrm{ppm}$ \\
Calcium (Ca) & $5.0 \mathrm{ppm}$ \\
Water insolubles & $5.0 \mathrm{ppm}$ \\
Particle size & $-200 \mathrm{mesh}$ \\
\hline Petroleum Coke (calcined) & \\
\hline Fixed carbon & $+99.0 \%$ \\
Ash content & $0.2 \%$ max. \\
Heavy metal (as Pb) & $0.005 \%$ max. \\
Silicon and iron & $0.1 \%$ max. \\
Particle size & -325 mesh (ASTM) \\
\hline
\end{tabular}

of carbon powder in a double cone blender. Part of the freshly mixed charge, together with furnace return (partially reduced fused mass) from a previous batch was charged around the graphite core. In the initial stages, furnace temperature waskept low, during which time boric acid dehydrated to boron anhydrides. Later on, power supply was increased to $>50 \mathrm{kw}$ to initiate reduction reaction. As the reaction progressed, the furnace was charged at regular intervals up to full capacity. The discharged carbon monoxide burnt with a bluish flame over the semi-fluid charge, and when the flame subsided the reaction was taken to be complete.

In the process of heating and reduction, the graphite core was slowly consumed, thereby increasing power density and temperature at the core, resulting in the formation of partially fused high-density carbide around it. Normally, after 12-14 hrs of heating the graphite core becomes substantially thinner, by which time the flame over the furnace charge has almost subsided. At this stage heating was discontinued and the furnace was allowed to cool to room temperature. The hard upper surface was broken with a pneumatic chipper or skull crusher, and the boron carbide powder and fused chunklets from inside the furnace recovered.

Crude carbide from the furnace was crushed in a jaw crusher to $6 \mathrm{~mm}$ pieces and then ground to powder in an impact pulveriser. This ground powder was subjected to magnetic separation for the removal of iron and manganese picked up during size reduction, and finally subjected to aqueous processing to get rid of residual impurities. 
TABLE 2: Effect of different types of carbon on production of boron carbide by carbothermic reduction

\begin{tabular}{|c|c|c|c|c|c|c|c|}
\hline $\begin{array}{l}\text { Expe- } \\
\text { riment } \\
\text { No. }\end{array}$ & $\begin{array}{l}\text { Type of } \\
\text { carbon } \\
\text { used }\end{array}$ & $\begin{array}{l}\text { Amount added } \\
\text { in the charge } \\
\text { (\% Stoichiometry) }\end{array}$ & $\begin{array}{l}\text { Boron } \\
\text { Carbide } \\
\text { yield }(\%)\end{array}$ & $\begin{array}{c}\text { Analysis } \\
\text { Boron }\end{array}$ & $\begin{array}{l}\text { of the pro } \\
\text { Total } \\
\text { Carbon }\end{array}$ & $\begin{array}{l}\text { luct \% } \\
\text { Free } \\
\text { Carbon }\end{array}$ & Remarks \\
\hline 1.1 & Activated & 90 & 28 & 78.5 & 19.0 & Nil & Very low bulk density, posed problem in mixing, \\
\hline 1.2 & Charcoal & 100 & 30 & 77.8 & 20.1 & Nil & substantial portion burnt at lower temp. Low \\
\hline 1.3 & $(0.5 \mu)$ & 110 & 32 & 76.8 & 21.0 & Nil & density flake-shaped product, poor vield. \\
\hline 1.4 & & 120 & 40 & 76.0 & 21.5 & 0.44 & \\
\hline 2.1 & Charcoal & 95 & 20 & 78.3 & 20.38 & Nil & Higher ash content $(<4 \%)$. \\
\hline 2.2 & $(-200$ mesh $)$ & 100 & 32 & 77.6 & 21.48 & Nil & Poor vield. Major fraction of the product was low \\
\hline 2.3 & & 110 & 35 & 77.3 & 22.50 & 1.08 & density power. \\
\hline 3.1 & Graphite & 95 & 25 & 76.5 & 19.8 & Nil & Sluggish reaction. \\
\hline 3.2 & $(-200$ mesh $)$ & 100 & 30 & 76.0 & 21.3 & 0.24 & Very poor conversion. \\
\hline 3.3 & & 105 & 32 & 76.2 & 22.0 & 0.88 & \\
\hline 3.4 & & 115 & 38 & 77.3 & 24.3 & 2.88 & \\
\hline 4.1 & Petroleum & 95 & 69.5 & 79.0 & 18.8 & Nil & No problem in mixing of the charge. \\
\hline 4.2 & Coke & 100 & 71.4 & 76.99 & 21.4 & 0.06 & Very low ash content. Good yield of dense, high \\
\hline 4.3 & $(-325$ mesh $)$ & 110 & 73.5 & 76.0 & 22.5 & 1.44 & density product. Very high conversion. \\
\hline
\end{tabular}

TABLE 3: Influence of boric acid to carbon ratio on boron carbide yield

\begin{tabular}{lllllll}
\hline $\begin{array}{l}\text { Experiment } \\
\text { No. }\end{array}$ & $\begin{array}{l}\text { Boric Acid } \\
\text { to } \\
\text { Carbon ratio }\end{array}$ & $\begin{array}{l}\text { Amount of Carbon } \\
\text { added in the charge } \\
\text { (\% Stoichiometry) }\end{array}$ & $\begin{array}{l}\text { Boron Carbide } \\
\text { conversion } \\
\text { (\% theoretical) }\end{array}$ & $\begin{array}{l}\text { Analysis of the product } \\
\text { Boron }\end{array}$ & $\begin{array}{l}\text { Carbon } \\
\%\end{array}$ & $\begin{array}{l}\text { Free Carbon } \\
\%\end{array}$ \\
\hline 4.4 & 3.00 & 102.0 & 72.0 & 76.0 & 21.39 & 0.24 \\
4.2 & 3.07 & 100.0 & 71.8 & 77.0 & 21.40 & 0.06 \\
4.5 & 3.10 & 98.5 & 71.5 & 76.8 & 21.0 & $<0.02$ \\
4.1 & 3.2 & 95.0 & 70.6 & 78.0 & 19.3 & $<0.02$ \\
4.6 & 3.3 & 93.0 & 69.6 & 79.3 & 18.8 & Nil \\
4.7 & 3.4 & 90.0 & 68.8 & 78.9 & 19.0 & - \\
4.8 & 3.5 & 88.0 & 66.5 & 78.0 & 18.9 & - \\
\hline
\end{tabular}

The aqueous processing of carbide involved leaching with hot $\left(80^{\circ} \mathrm{C}\right) \mathrm{HCl}$, and then with $2 \%$ solution of caustic soda which removed residual iron and unreacted oxide respectively. After thorough washing the powder was dried at $200^{\circ} \mathrm{C}$ in an oven. A purified sample of carbide was analysed for total boron and carbon content.

\section{RESULTS AND DISCUSSIONS}

A series of experiments was conducted to study the influence of various process parameters such as (i) different types of commercially available carbon as a reducing agent, (ii) boric acid to carbon ratio in the charge and (iii) test duration and rate of heating on boron carbide yield and quality. The results are summarised in Tables 2, 3 and 4.

\section{(i) Types of carbon as reducing agent:}

Exploratory experiments carried out using activated charcoal as reducing agent were not very encouraging. Due to low bulk density of this variety of carbon it was very difficult to get a homogeneous charge mix. ture. Moreover, a substantial portion of carbon burnt at lower temperature due to its higher reactivity. It may be seen in Table 2 that maximum carbide yield, even with $120 \%$ stoichiometric carbon in the charge, was only $40 \%$. The fine flake-shaped product obtained from these runs had very low bulk density. 
TABLE 4: Influence of rate of heating and duration of run on carbide yield

\begin{tabular}{|c|c|c|c|c|c|c|c|c|c|}
\hline $\begin{array}{l}\text { Experi- } \\
\text { ment } \\
\text { No. }\end{array}$ & \multicolumn{2}{|c|}{$\begin{array}{c}\text { Initial power } \\
\text { rating } \\
\text { Voltage Current }\end{array}$} & \multicolumn{2}{|c|}{$\begin{array}{c}\text { Max. power } \\
\text { rating } \\
\text { Voltage Current }\end{array}$} & $\begin{array}{l}\text { Time } \\
\text { required } \\
\text { to reach } \\
\text { max. power }\end{array}$ & $\begin{array}{l}\text { Rate of } \\
\text { heating } \\
\text { KVA/hr }\end{array}$ & $\begin{array}{l}\text { Duration } \\
\text { of run } \\
\text { hr. }\end{array}$ & $\begin{array}{l}\text { Boron carbide } \\
\text { conversion } \\
\%\end{array}$ & Product quality \\
\hline 4.10 & 15 & 1200 & 30 & 1800 & 4.0 & 9.0 & 12 & 67 & Fine, low density powder \\
\hline 4.11 & 20 & 1200 & 30 & 1800 & 2.0 & 15.0 & 12 & 69.8 & $40 \%$ partially sintered and dense product \\
\hline 4.1 & 20 & 1200 & 30 & 1800 & 1.0 & 30.0 & 12 & 72.0 & $50 \%$ partially sintered and dense product \\
\hline 4.12 & 20 & 1200 & 31 & 1800 & 0.5 & 64.0 & 11 & 65 & $50 \%$ partially sintered and dense product \\
\hline 4.13 & 20 & 1200 & 30 & 1800 & 1.0 & 30.0 & 10 & 68 & $50 \%$ partially sintered and dense product \\
\hline 4.14 & 20 & 1200 & 30 & 1800 & 1.0 & 30.0 & 14 & 73 & $50 \%$ partially sintered and dense product \\
\hline
\end{tabular}

Use of charcoal powder as reductant resulted in marginal improvement in the yield. The major portion of the products in this case was also found to be low density powder. High ash content $(>4 \%)$ in charcoal contaminated the product with mineral impurities.

In order to avoid transfer of impurities from the reductant, the use of high purity graphite was contemplated in the following experiments. Though the quality of the products obtained from these runs was quite satisfactory, the reaction appeared to be very sluggish. In 12 hrs test duration a maximum of only $35 \%$ conversion could be achieved with such graphite reductant.

The best results were obtained when petroleum coke powder was used as reducing agent. Indigenously available coke powder used in this reduction campaign contained very low ash content (200 ppm). Charge mixture prepared with this carbon in a cone blender was homogeneous. Reduction reaction with this charge proceeded at a reasonably fast rate, and in $12 \mathrm{hrs}$ run more than $70 \%$ (vide Table 2) conversion could be achieved. About $50 \%$ of the product obtained was partially fused chunklets having very high density and purity.

\section{(ii) Boric acid to carbon ratio}

After ascertaining petroleum coke to be the best reducing agent, a series of experiments were conducted to discover optimum boric acid to carbon ratio for maximum yield of good quality carbide. It may be seen in Table 3 that the product obtained by reacting a charge composed of boric acid and carbon in the ratio $3.07: 1$ or $3.00: 1$ (100 and $102 \%$ stoichiometric carbon) contained more than $0.06 \%$ free carbon. This was primarily due to deficiency of boric acid caused by its volatilization in presence steam at the early stages of heating. As a remedial measure to this situation, increased amounts of boric acid were added in the charge in the next five experiments. It can be seen from the Table that, as the boric acid to carbon ratio was increased from 3.07 to 3.3 , boron content of the product improved from 77.0 to $79.3 \mathrm{wt} \%$, and free carbon reduced from 0.06 to $<0.02 \%$ respectively. However, a slight fall in the boron carbide conversion was noticed due to deficiency of carbon in the charge. Boric acid to carbon ratio of 3.3 was considered ideal from the point of view of carbide yield and quality.

\section{(iil) Rate of heating and duration of test run}

Rate of heating of the furnace was observed to have profound influence on boron carbide conversion. It can be seen in Table 4 that when the rate of heating to reach maximum power (54 KVA) was increased from $9 \mathrm{KVA} / \mathrm{hr}$ to $30 \mathrm{KVA} / \mathrm{hr}$, corresponding yield improved from 67 to $72 \%$. Faster rate of heating also helped in producing higher amounts of partially sintered and dense carbide. However, further increase in the rate of heating $(64 \mathrm{KVA} / \mathrm{hr})$ resulted in poor recovery due to loss of boric acid at the initial stages. Consumption of core rod in this case was also faster, and the rod snapped after 11 hrs of heating.

A test duration of $12 \mathrm{hrs}$ was found to give maximum yield (72\%) with this furnace configuration and power supply. Extending duration to $14 \mathrm{hrs}$ was not considered beneficial as the yield improved only mar. ginally.

The operating parameters standardized from aforementioned experimental studies is given in Table 5 . It may be seen that on an average, about $70 \%$ of boron in the charge got converted to boron carbide. Normally about $25 \%$ of the partially reduced furnace burden 
TABLE 5: Typical operational data for the production of boron carbide

\begin{tabular}{|c|c|}
\hline Raw material & Boric acid and Petroleum Coke \\
\hline \multicolumn{2}{|l|}{ Furnace: } \\
\hline Type & Resistance \\
\hline \multirow[t]{3}{*}{ Size } & $1500 \mathrm{~mm}$ long \\
\hline & $250 \mathrm{~mm}$ wide \\
\hline & $1000 \mathrm{~mm}$ ht. \\
\hline Walls & Graphite backed by refractory lining. \\
\hline Terminais & Water cooled graphite \\
\hline Heating element & $36 \mathrm{~mm}$ dia, $1000 \mathrm{~mm}$ \\
\hline Initial voltage (V) & 20 \\
\hline current (A) & 1200 \\
\hline \multirow{3}{*}{$\begin{array}{l}\text { Final voltage (V) } \\
\text { current (A) } \\
\text { Charge capacity }- \text { per batch }(\mathrm{Kg} .)\end{array}$} & 30 \\
\hline & 1800 \\
\hline & $50-60$ \\
\hline Maximum temperature at the core $\left({ }^{\circ} \mathrm{C}\right)$ & $>2000$ \\
\hline Furnace wall temperature $\left(^{\circ} \mathrm{C}\right)$ & 80 \\
\hline Length of operation (hrs.) & 12 \\
\hline \% Conversion per batch & $70 \%$ \\
\hline Boron Carbide production/batch (Kg.) & 12 \\
\hline Energy consumption ( $\mathrm{Kwh} / \mathrm{Kg}$. ) & 36 \\
\hline
\end{tabular}

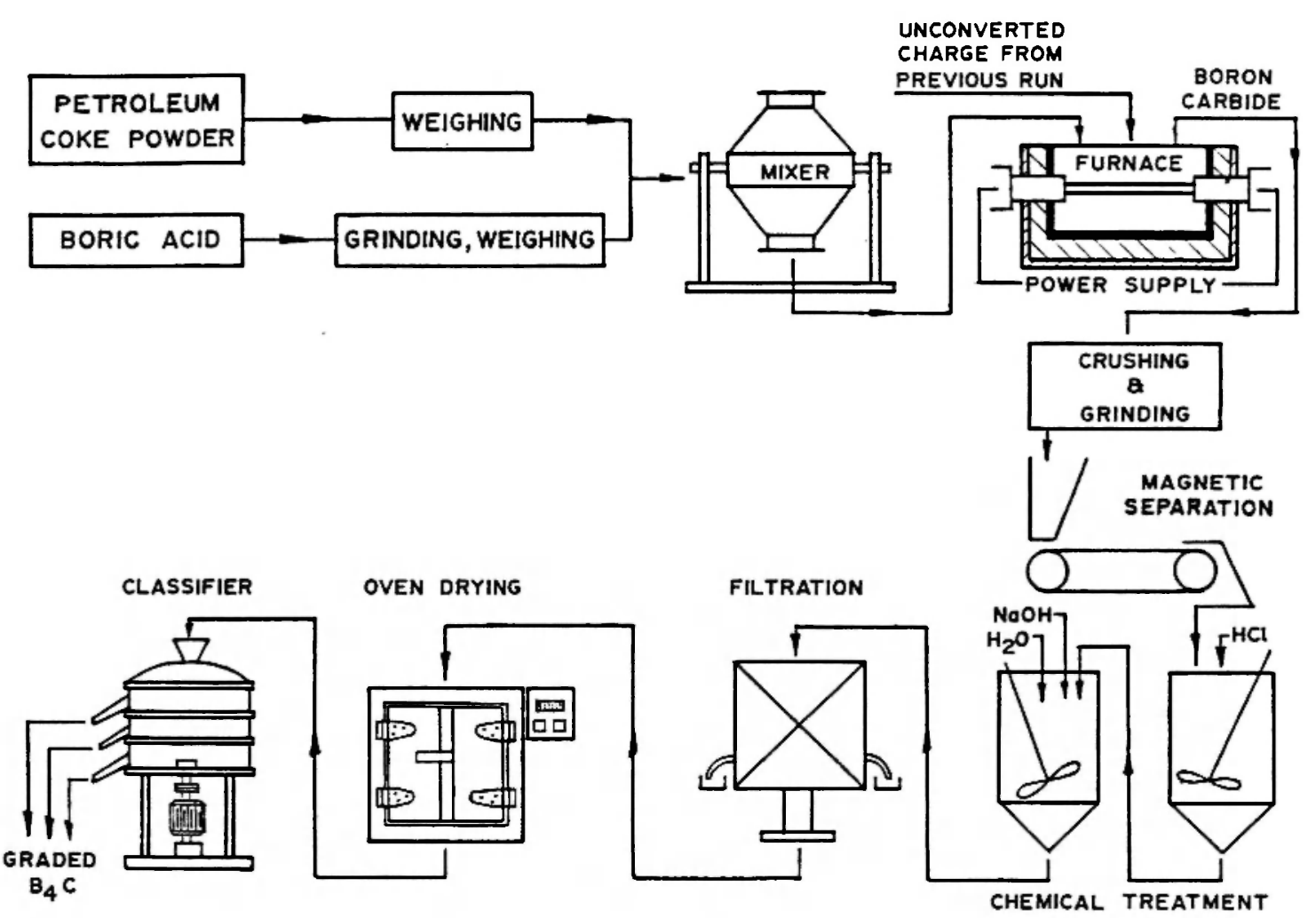

Fig. 2. Flow sheet for the production of boron carbide.

was returned to the next melt. As a result, actual loss of boron due to volatilization amounted to about 5\%. Fig. 2 presents a complete flowsheet for the production of nuclear grade boron carbide as established in the present investigation. Fig. 3 shows a photograph of $\mathrm{B}_{4} \mathrm{C}$ chunklet and powder freshly removed from the furnace. 


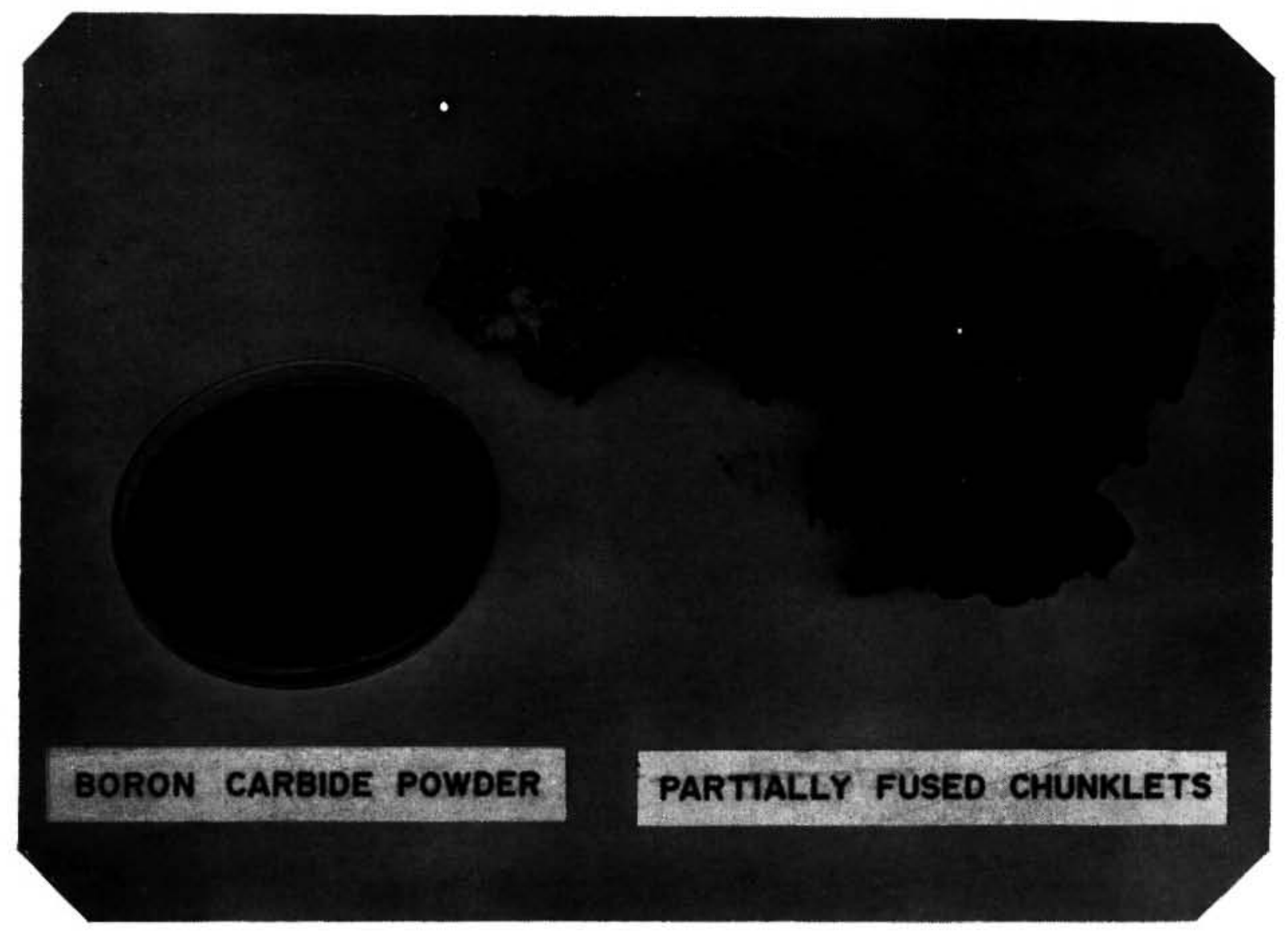

Fig. 3. Boron carbide powder and partially fused chunklets as received from the furnace.

\section{PROCESSING OF BORON CARBIDE FOR CONTROL ROD AND SHIELDING APPLICATION}

High purity boron carbide $(>78 \%$ B) powder blends having high tap density (> $1.68 \mathrm{~g} / \mathrm{cc}$ ) are used for the fabrication of control rods for BWR type reactors. Partially fused boron carbide chunklets obtained from this bench scale operation were found to be ideal for the preparation of control rod powder blend. The chunklets, after crushing, grinding and magnetic separation were subjected to similar chemical treatments as described earlier. Analysis of high purity carbide powder obtained from this operation is given in Table 6. The powder was classified in three size ranges, i.e. (i) $-16+20$ mesh, (ii) $-60+80$ mesh and (iii) $-200+$ 325 mesh. A blend composed of 40,20 and $40 \%$ of these three fractions gave a bulk density $>1.60 \mathrm{~g} / \mathrm{cc}$ and tap density $>1.7 \mathrm{~g} / \mathrm{cc}$. This powder blend in $6 \mathrm{~mm}$ dia S.S. tubes was used for the fabrication of control rod assembly.
TABLE 6: Chemical analysis of boron carbide

\begin{tabular}{lc}
\hline Boron & $78.45 \mathrm{wt} \%$ \\
Carbon & $20.37 \mathrm{wt} \%$ \\
$\mathrm{~B}^{10} / \mathrm{B}^{11}$ ratio & $0.25 \pm 0.002$ \\
\hline Impurity Elements & Impurity level (ppm) \\
$\mathrm{Si}$ & 1500 \\
$\mathrm{Cl}$ and $\mathrm{F}$ & 10 \\
$\mathrm{Fe}$ & 1300 \\
$\mathrm{Co}$ & 1 \\
$\mathrm{Mn}$ & 12 \\
$\mathrm{Na}$ & 30 \\
$\mathrm{~K}$ & 5 \\
$\mathrm{~B}$ & $\mathrm{O}_{3}$ \\
$\mathrm{Moisture}$ & 1000 \\
\hline
\end{tabular}

About 50 to $55 \%$ powder product recovered from the furnace was found unsuitable for use in control rods, but could be used for shielding application, as 
its average boron content was more than $76 \%$. After requisite classification, this powder fraction was successfully used for the fabrication of shielding materials such as boral (Aluminium bonded $\mathrm{B}_{4} \mathrm{C}$ ) and boron carbide incorporated resin/silicone rubber shapes.

\section{CONCLUSION}

The work has demonstrated the technical feasibility of bench scale production of high quality boron carbide by the carbothermic reduction of boric acid in a graphite resistance furnace. The product obtained from this operation has been successfully used as a neutron absorber in the fabrication of control rods and shielding materials for nuclear reactors.

\section{REFERENCES}

1. MEerson, G.A. and SAMSONOV, G.V., Proc. Conf. on boron and its compounds, M. GHI, USSR, 52-59 (1958).

2. SAMSONOV, G.V., Ukr. Chem. J., 24: 799-805 (1958).

3. COCHRAN, A.A. and STEPHENSON, J.B., Met. Trans., 1: 2875 (1970).

4. PLOOG, K. and AMBERGER, E., J. Less Common Metals, 23: 33-42 (1971).

5. MARKOVSKII, L.Ya., ORSHANSKII, D.L. and PRIANISHNIKOV, V., Electrothermic Chemistry M-L, USSR: Goshimizdat (1952). 